\title{
UPAYA MENINGKATKAN KEAKTIFAN SISWA DALAM PEMBELAJARAN JARAK JAUH (DISTANCE LEARNING) BERBANTUAN MODA KOMBINASI PADA MATERI INTERAKSI SOSIAL DI KELAS VII D SMPN 1 LABUHAN HAJI SEMESTER GANJIL TAHUN PELAJARAN 2020/2021
}

\author{
Laili Ismini \\ SMP NEGERI 1 LABUHAN HAJI \\ laili ismini@gmail.com
}

\begin{abstract}
Abstrak
Penelitian ini merupakan penelitian tindakan kelas yang bertujuan untuk mengetahui dan menemukan model pembelajaran yang dapat meningkatkan keaktifan siswa dalam pembelajaran jarak jauh. Sampel dalam penelitian ini adalah kelas VII D SMP Negeri 1 labuhan haji semester ganjil tahun pelajaran 2020/2021. Penelitian ini dilaksanakan dalam dua siklus dengan masing-masing siklus dilaksanakan dua kali pertemuan. Masing-masing siklus terdiri dari empat fase yaitu : fase perencanaan, fase pelaksanaan, fase pengamatan, dan fase refleksi. Pengumpulan data dalam penelitian ini dilakukan melalui observasi, angket dan studi dokumentasi. Hasil penelitian menunjukkan bahwa penerapan moda kombinasi dapat meningkatkan keaktifan siswa dalam pembelajaran jarak jauh (Distance Learning) pada materi Interaksi Sosial di kelas VII D SMPN 1 Labuhan Haji Semester Ganjil Tahun Pelajaran 2020/2021, yaitu peningkatan keaktifan siswa dalam mengikuti proses pembelajaran maupun keaktifan dalam mengumpulkan tugas-tugas yang diberikan guru.
\end{abstract}

Kata Kunci : moda kombinasi, pembelajaran jarak jauh, keaktifan siswa

\begin{abstract}
This research is a classroom action research that aims to find out and find a learning model that can increase student activity in distance learning. The sample in this study was class VII D of SMP Negeri 1 Labuhan Haji in the odd semester of the 2020/2021 school year. This research was carried out in two cycles with each cycle being carried out in two meetings. Each cycle consists of four phases, namely: the planning phase, the implementation phase, the observation phase, and the reflection phase. Data collection in this study was carried out through observation, questionnaires and documentation studies. The results showed that the application of the combination mode can increase student activity in distance learning (Distance Learning) on Social Interaction material in class VII D SMPN 1 Labuhan Haji Odd Semester for the 2020/2021 Academic Year, namely increasing student activity in participating in the learning process and activeness in collect the assignments given by the teacher
\end{abstract}

Keywords: combination mode, distance learning, student activity 


\section{PENDAHULUAN}

Pendidikan tidak dapat dipisahkan dari kehidupan manusia. Begitu penting-nya pendidikan sehingga pemerintah berkewajiban memenuhi hak atas pendidikan bagi setiap warga negaranya tanpa terkecuali baik melalui jalur formal maupun non formal. Hal ini merupakan perwujudan pasal 31 Undang-Undang Dasar 1945 ayat (1) yang menyatakan bahwa setiap warga negara berhak mendapatkan pendidikan yang layak, terutama pendidikan dasar..

Pada masa pandemi seperti sekarang ini pendidikan harus tetap berjalan meskipun dalam keadaan terbatas dan tidak memungkinkan untuk melaksanakan pembelajaran di sekolah secara normal melalui pembelajaran tatap muka.

Inilah yang menjadi alasan utama pemerintah mengeluarkan kebijakan yang meminta siswa belajar dari rumah (BDR) sehingga segala aktivitas yang memungkinkan terjadinya kerumunan dapat dicegah. Tujuan pembelajaran model BDR relatif sama dengan model BDS (belajar di seklolah) hanya saja sarana pendukung yang dibutuhkan berbeda.

Sistem pembelajaran model BDR atau sering juga disebut pembelajaran jarak jauh (PJJ) adalah pembelajaran yang dilakukan tanpa tatap muka secara langsung antara guru dan siswa akan tetapi kegiatan dilakukan secara daring (dalam jaringan) menggunakan jaringan internet dengan memanfaatkan beberapa aplikasi seperti google classroom, office 365, zoom, WhatsApp dan lain sebagainya.

Terjadinya perubahan sistem pembelajaran yang sangat mendadak dan tanpa ini menyebabkan terjadinya kegagapan baik bagi guru maupun siswa karena sistem pembelajaran daring membutuhkan persiapan dalam proses belajar mengajar dengan memanfaatkan tehnologi pembelajaran yang betul-betul berbeda dari sebelumnya pada semua jenjang pendidikan. Selain permasalahan kurangnya kemampuan guru dan siswa dalam memanfaatkan tehnologi digital dalam proses pembelajaran, masih terdapat beberapa kendala yang dihadapi siswa seperti ; tidak memiliki Hand Phone (HP), Hand Phone yang dimiliki ukan android, kuota internet yang sangat terbatas, jaringan internet yang tidak stabil, dan lainlain.

Selain kendala berupa terbatasnya ketersediaan sarana belajar daring di atas, menurunnya semangat belajar siswa juga menyebabkan kurang aktifnya mereka dalam proses pembelajaran. Hal ini juga merupakan permasalahan yang perlu mendapat perhatian serius demi kelancaran proses pembelajaran. Ketidak aktifan tersebut terlihat dari sikap tidak peduli siswa dan kurangnya tanggung jawab siswa dalam mengikuti pembelajaran maupun dalam menye-lesaikan tugas-tugas yang diberikan guru.

Selain itu banyak di antara siswa yang kesulitan memahami materi pelajaran, sementara mereka tidak leluasa bertanya karena keterbatasan ruang gerak dan ruang komunikasi dalam proses pembelajaran jarak jauh. Melihat kondisi seperti ini peneliti merasa tertarik untuk melakukan penelitian tindakan kelas dengan mengkombinasikan pembelajaran secara daring dengan luring dalam pelaksanaan model pembelajaran Distance Learning (pembelajaran jarak jauh) dengan judul “ Upaya Meningkat-kan Keaktifan Siswa dalam Pembelajaran Jarak Jauh (Distance Learning) Berbantuan Moda Kombinasi pada materi Interaksi Sosial di kelas VII D SMPN 1 Labuhan Haji Semester Ganjil Tahun Pelajaran 2020/2021”.

Adapun permasalahan yang ingin dijawab dalam penelitian ini berdasarkan uraian di atas, adalah : bagaimanakah mode kombinasi dapat meningkatkan keaktifan siswa dalam pembelajaran jarak jauh pada siswa kelas VII D di SMPN 1 Labuhan Haji?

Dengan demikian maka tujuan penelitian tindakan kelas ini adalah : untuk menemukan model pembelajaran yang dapat 
meningkatkan keaktifan siswa dalam pembelajaran jarak jauh dan secara khusus untuk mengetahui bagaimanakah mode kombinasi dapat meningkatkan keaktifan siswa dalam pembelajaran jarak jauh.

Adapun manfaat yang diharapkan dapat diperoleh dari hasil penelitian tindakan kelas ini, secara teoritis diharapkan dapat menambah sumber pengetahuan mengenai model pembelajaran distance learning, menjadi referensi bagi penelitian sejenis pada masa yang akan dating, dan berkontribusi dalam bidang pendidikan khususnya pengembangan model pembelajaran, sedangkan manfaat yang diharapkan secara praktis adalah siswa lebih aktif dalam mengikuti pembelajaran jarak jauh baik daring maupun luring, dan peneliti mempunyai landasan dalam mengembangkan model pembelajaran pada masa pandemic.

Berbicara tentang pembelajaran jarak jauh, keberhasilan penggunaan strategi moda kombinasi dalam meningkatkan keaktifan siswa dalam pembelajaran jarak jauh telah diungkapkan oleh Mustakim dalm penalitiannya yang berjudul " Efektivitas Pembelajaran Daring Menggunakan Media Online selama Pandemi Covid-19 Pada Mata Pelajaran Matematika". Hasil penelitian ini menyimpulkan bahwa $23,3 \%$ peserta didik menilai inovasi pembelajaran yang dilakukan oleh guru matematika yakni dengan menggunakan media online sangat efektif dalam membantu peserta didik menjalani pembelajaran daring selama pandemi covid19 ini, $(46,7 \%)$ peserta didik menilai efektif, $20 \%$ peserta didik menilai biasa saja, dan hanya $10 \%$ peserta didik yang menganggap pembelajaran daring tidak efektif. (mustaqim, 2020)

Sebagai penelitiann tindakan kelas, variabel dalam penelitian ini terdiri dari dua variabel utama, yaitu variabel tindakan dan variabel harapan.

Variabel tindakan adalah upaya yang dilakukan guru untuk mencapai tujuan yang diinginkan, dalam hal ini adalah strategi moda kombinasi, yaitu dengan memadukan sistem pembelajaran daring (dalam jaringan) dan luring (luar jaringan). Pembelajaran daring yaitu suatu bentuk pembelajaran jarak jauh yang memanfaatkan teknologi telekomunikasi dan informasi, (Molinda, 2005) sehingga dapat terjadi komunikasi dua arah antara guru dan siswa, sedangkan pembelajaran luring (luar jaringan), menurut KBBI diartikan sebagai terputus dari jejaring komputer maupun internet. Dengan kata lain, pembelajaran luring adalah proses pembelajaran yang tidak melibatkan jaringan internet. Moda kombinasi ini dipilih sebagai alternatif untuk mengatasi permasalahan kurangnya keaktifan peserta didik dalam proses pembelajaran.

Dengan adanya strategi pembe-lajaran memudahkan guru dalam proses belajar mengajar. Begitu pula peserta didik lebih mudah memahami materi dan termotivasi dalam belajar. Hal ini sesuai dengan pendapat Alim Sumarno yang mengatakan strategi pembelajaran sebagai kegiatan yang dipilih oleh guru dalam proses pembelajaran yang dapat memberikan kemudahan fasilitas kepada peserta didik menuju kepada tercapainya tujuan pembelajaran tertentu yang telah ditetapkan."(Alim Sumarno ,2011)

Variabel harapan adalah suatu kondisi yang diinginkan terjadi dari upaya yang telah dilakukan, dalam hal ini adalah keaktifan siswa, yaitu kegiatan yang bersifat fisik maupun mental, berbuat dan berfikir sebagai suatu rangkaian yang tidak dapat dipisahkan (Sardiman, 2001: 98).

Kegiatan atau aktifitas fisik adalah dimana peseta didik giat aktif dengan anggota badan, membuat sesuatu, bermain maupun bekerja, ia tidak hanya duduk dan mendengarkan, melihat atau hanya pasif, sedangkan aktifitas psikis (mental/kejiwaan) adalah jika daya jiwanya bekerja sebanyakbanyaknya atau banyak berfungsi dalam rangka pembelajaran

Menurut Nana Sudjana (2005) keaktifan peserta didik dapat dilihat dari 
keikutsertaan peserta didik dalam melaksanakan tugas belajarnya, terlibat dalam memecahkan masalah, bertanya kepada guru atau temannya apabila tidak memahami persoalan yang dihadapi, berusaha mencari berbagai informasi yang diperlukan untuk memecahkan masalah, melatih diri dalam menyelesaikan masalah atau soal, serta menilai kemampuan diri sendiri.

Djoko Santoso dkk (2007) menjelaskan bahwa pembelajaran yang berkualitas adalah terlibatnya peserta didik secara aktif dalam pembelajaran. Keterlibatan yang dimaksud adalah aktivitas mendengarkan, komitmen terhadap tugas, mendorong berpartisipasi, menghargai kontribusi/pendapat, mene-rima tanggung jawab, bertanya kepada pengajar atau teman dan merespon pertanyaan.

Menurut UU nomor 20 tahun 2003 pasal 1 ayat 15 yang isinya "Pendidikan jarak jauh adalah pendidikan yang perserta didiknya terpisah dari pendidik dan pembelajarannya menggunakan berbagai sumber belajar melalui teknologi komunikasi, informasi dan media lain."Oleh karena itu sering disebut pembelajaran berbasis teknologi informasi dengan memanfaatkan media online/internet yang berisi bahan ajar, soal-soal latihan dan forum diskusi yang dikemas dalam berbagai pilihan aplikasi pembelajaran

Berdasarkan uraian tersebut di atas, maka peneliti mengajukan hipotesis sebagai berikut : keaktifan peserta didik akan meningkat jika pembelajaran jarak jauh dilaksanakan dengan menerapkan strategi moda kombinasi, karena dapat mengatasi kendala dalam pembelajaran daring.

\section{METODE PENELITIAN}

Penelitian ini merupakan penelitian tindakan kelas (PTK) yang dilakukan pada siswa kelas VII D SMP Negeri 1 Labuhan Haji pada tahun pelajaran 2020/2021 semester ganjil dengan jumlah siswa 29 orang yang terdiri dari 16 orang laki-laki dan 13 orang perempuan.

Penelitian ini dilaksanakan dalam dua siklus dengan masing-masing siklus dilaksanakan dua kali pertemuan. Masingmasing siklus terdiri dari empat fase yaitu : fase perencanaan, fase pelaksanaan, fase pengamatan, dan fase refleksi.

Pada masing-masing fase kegiatan dilakukan langkah-langkah sebagai beri-kut :

1. Fase perencanaan : menyiapkan materi sesuai KD yang akan diajarkan, pembuatan RPP tentang materi yang akan diajarkan dengan moda kombinasi, merancang instrumen sebagai pedoman observasi tentang keaktifan siswa, mempersiapkan sarana dan prasarana (media pembelajaran) yang akan diperguna-kan saat proses KBM berlangsung. menyusun dan mempersiapkan lembar kerja siswa, serta menyusun angket keaktifan siswa.

2. Fase pelaksanaan : pada fase ini guru melaksanakan pembelajaran berdsar-kan skenario pembelajaran yang terdapat dalam recana pelaksanaan pembelajaran (RPP) yang telah disusun pada fase perencanaan. Guru mengirim materi dan lembar tugas yang telah disiapkan melalui aplikasi google classroom, office 365, zoom, WhatsApp. Dalam peaksanaan pembelajaran ini juga dilakukan tindakan sebagaimana yang telah ditetepkan.

3. Fase pengamatan/observasi : pada fase ini dilakukan pengamatan terhadap pelaksanaan pembelajaran yang dilakukan berkaitan dengan bagaimana penerapan moda kombinasi yang dilakukan oleh guru serta bagaimana keaktifan siswa dengan diterapkannya model pembelajaran tersebut. Penga-matan dilakukan dengan berpedoman pada instrumen pengamatan/observasi yang telah disiapkan. Dalam mela-kukan pengamatan, peneliti didam-pingi oleh seorang guru sebagai observer. Selanjutkan peneliti (guru) bersama 
observer melakukan analisis terhadap hasil pengamatan yang telah dilakukan.

4. Fase refleksi : kegiatan refleksi ini merupakan kelanjutan dari kegiatan yang dilakukan pada fase sebelumnya. Reflesi dilakukan berdasarkan hasil analisis terhadap hasil pengamatan yang telah dilakukan. Selanjutnya hasil refleksi ini akan dijadikan sebagai bahan untuk menyusun perencanaan pada siklus berikutnya.

Pengumpulan data dalam penelitian ini dilakukan melalui observasi, angket dan studi dokumentasi. Observasi digunakan untuk mencari data tentang tingkat keaktifan siswa pada proses pelaksanaan pembelajaran pra siklus dan kegiatan siklus satu maupun dua. Adapun studi dokumentasi dilakukan untuk menggali data-data pendukung yang akan digunakan untuk melengkapi data keakti-fan siswa, dokumen yang digunakan adalah bukti catatan pengumpulan tugas dan catatan aktivitas siswa dalam pembelajaran.

Adapun alat atau instrumen yang digunakan untuk mengumpulkan data penelitian adalah lembar observasi, dan lembar check list studi dokumentasi.

\section{HASIL PENELITIAN DAN PEMBAHASAN}

\section{Kondisi Awal (PraSiklus)}

Pelaksanaan tindakan penelitian prasiklus dimulai dengan mengadakan observasi awal yang dilakukan pada hari Rabu, 9 september 2020. Kegiatan ini meliputi kegiatan observasi kelas dan diskusi dengan rekan guru pengajar lainnya untuk mendapatkan gambaran tentang kondisi siswa dan tindakan yang perlu diambil.

Pada observasi awal serta hasil diskusi dengan guru lainnya, peneliti menemukan beberapa hal yaitu, kurangnya keaktifan siswa dalam pembelajaran daring. Hal ini di-buktikan dengan banyaknya siswa yang tidak mengikuti pembelajaran selama proses pembelajaran dan lebih dari $30 \%$ siswa tidak mengumpulkan tugas.

Setelah mengetahui kondisi pembelajaran dan menemukan permasalahan berupa rendahnya keaktifan siswa dalam proses pembelajaran, peneliti melakukan diskusi lanjutan dengan guru mata pelajaran lain yang mengajar di kelas yang akan diberi tindakan dan guru mata pelajaran IPS yang ada di sekolah tersebut untuk membahas cara atau tindakan yang dapat dilakukan untuk meningkatkan keaktifan siswa. Dalam diskusi lanjutan ini disimpulkan bahwa penggunaan strategi Moda Kombinasi dalam pembelajaran jarak jauh diperkirakan paling sesuai diterapkan untuk meningkatkan keaktifan siswa dalam mengikuti proses pembelajaran khususnya pada mata pelajaran IPS. Selain pemilihan strategi pembelaja-ran, dilakukan pula pendekatan kepada siswa terutama siswa yang tampak tidak aktif dalam pembelajaran.

Setelah guru/peneliti melakukan pendekatan, ditemukan beberapa hal yang menjadi penyebab ketidak aktifan siswa dalam pembelajaran, seperti ;

a. Siswa merasa kesulitan memahami materi yang berikan oleh guru lewat aplikasi daring.

b. Siswa merasa malu untuk bertanya kepada guru.

c. Beberapa siswa tidak memiliki Hand Phone android

d. Siswa tidak memiliki kuota yang cukup untuk mengikuti pembelaja-ran daring.

e. Jaringan internet sering bermasalah

Selama observasi awal diperoleh informasi bahwa masih banyak siswa yang kesulitan mengikuti pembelaja-ran daring, hal ini tentunya sangat berpengaruh terhadap hasil belajar yang masih banyak di bawah nilai ketuntasan serta berpengaruh pula terhadap persentase siswa yang mengumpulkan 
tugas. Sebagaimana dalam table berikut ini:

Tabel Hasil Penugasan PraSiklus

\begin{tabular}{|l|c|}
\hline Nilai Tertinggi & $\mathbf{8 5}$ \\
\hline Nilai Terendah & $\mathbf{0}$ \\
\hline Rata-rata & $\mathbf{5 0}$ \\
\hline Prosentase Ketuntasan & $\mathbf{5 5 \%}$ \\
\hline
\end{tabular}

Persentase ketuntasan di atas diperoleh berdsarkan data bahwa dari 29 siswa kelas VII D, 19 siswa (65\%) mengumpulkan tugas dan 10 siswa (35\%) tidak mengumpulkan tugas. Namun dari 19 siswa mengumpulkan tugas, 16 siswa (55\%) mendapat nilai tuntas dan 3 siswa (10\%) mendapat nilai belum tuntas.

Adapun interval nilai penugasan PraSiklus sebagaimana dalam table berikut ini:

Tabel Interval nilai penugasan PraSiklus

\begin{tabular}{|c|c|c|}
\hline No & $\begin{array}{c}\text { Interval } \\
\text { Nilai }\end{array}$ & $\begin{array}{c}\text { Banyak } \\
\text { Siswa }\end{array}$ \\
\hline 1 & $0-50$ & 10 \\
\hline 2 & $51-60$ & 1 \\
\hline 3 & $61-70$ & 4 \\
\hline 4 & $71-80$ & 8 \\
\hline 5 & $81-90$ & 6 \\
\hline 6 & $91-100$ & 0 \\
\hline \multicolumn{2}{|c|}{ Jumlah } & 29 \\
\hline
\end{tabular}

2. Deskripsi Siklus I

Tindakan pada siklus 1 ini dilaksanakan pada hari Sabtu, 3 Oktober 2020. Pada pelaksanaan siklus I ini, peneliti didampingi salah seorang guru IPS di SMPN 1 Labuhan Haji sebagai observer yaitu Rukaiyah, S.Pd.

Langkah-langkah yang dilaku-kan pada siklus 1 ini, sebagai berikut:

\section{a. Perencanaan}

Pada tahap perencanaan ini, guru menyiapkan rencana pembelajaran dengan mempertimbangkan hasil pengamatan pada prasiklus. Oleh karena itu tahap siklus 1 ini menekankan pada penggunaan strategi
Moda Kombinasi. Pada tahap ini yang dipersiapkan adalah:

1) RPP

2) Lembar observasi

3) Materi dan media pembelajaran.

b. Pelaksanaan

Pada tahap pelaksanaan, peneliti melaksanakan tindakan sesuai dengan RPP yang telah disiapkan sebelumnya dengan langkah-langkah sebagai berikut:

- Kegiatan Pendahuluan :

1) Menginformasikan melalui grup WA dan Microsoft Team.

2) Mengucap salam dan berdo'a, dilanjutkan dengan mengecek kehadiran siswa lewat WAG/ Microsoft Team.

3) Apersepsi dan motivasi dengan menanyakan tentang video yang telah dikirim oleh guru/peneliti sehari sebelum pembelajaran pada siklus 1.

- Kegiatan Inti :

Dilaksanakan secara daring

Pertemuan I :

1) Mengirimkan link untuk bisa join di Room Virtual Microsoft Team

2) Guru / peneliti menjelaskan materi pelajaran sesuai KD dalam RPP yang disiapkan yaitu tentang Interaksi Sosial.

3) Guru / peneliti mempersilahkan siswa untuk bertanya jika ada yang belum dipahami dari penjelasan guru.

4) Guru meminta masing-masing siswa untuk membuat contoh interaksi social antara individu dengan individu, individu dengan kelompok, kelompok dengan kelompok. Selanjutnya memberikan kesempatan kepada siswa untuk mempersentasikan nya.

5) Menyimpulkan dengan cara membuat rangkuman hasil pembelajaran dan menyelesai-kan 
tugas yang diberikan guru secara tertulis.

6) Guru memberikan kesempatan kepada siswa untuk berdiskusi melalui WAG.

Dilaksanakan secara luring :

1) Siswa menyelesaikan tugas yang diberikan guru yaitu meminta siswa untuk membuat foto pribadi dengan keluarga maupun temannya yang memperagakan contoh interaksi social antara individu dan individu, individu dengan kelompok, dan kelompok dengan kelompok.

2) Siswa mengirimkan tugasnya lewat WAG/Microsoft Team.

Dilaksanakan secara daring

Pertemuan II :

1) Membuka pembelajaran dengan voice call melalui WAG.

2) Menjelaskan secara singkat materi pelajaran tentang ciri-ciri Interaksi Sosial.

3) Mempersilahkan siswa untuk bertanya jika ada yang belum dipahami dari penjelasan guru melalui voice call atau komen lewat WAG.

Dilaksanakan secara luring :

1) Siswa menyelesaikan tugas yang diberikan guru yaitu meminta siswa untuk membuat video pendek dengan keluarga maupun temannya yang memperagakan contoh interaksi social antara individu dan individu, individu dengan kelompok, dan kelom-pok dengan kelompok yang mengandung ciriciri interaksi Sosial.

2) Memberikan keterangan secara singkat tentang video yang telah dibuat.

3) Siswa mengirimkan tugasnya lewat WAG/Microsoft Team.

\section{c. Pengamatan}

Pengamatan (observasi) dilaksanakan bersamaan dengan tindakan dalam proses pembelaja-ran bersama seorang observer. Hasil pengamatan menunjukkan sebagian siswa tidak aktif dalam diskusi kelompok, siswa masih enggan untuk bertanya pada proses pembelajaran. Jika ditanya guru ternyata belum sepenuhnya bisa menjawab pertanyaan.

Berdasarkan hasil observasi keaktifan siswa pada siklus I diperoleh informasi bahwa terdapat 10 orang siswa yang aktif, 10 orang siswa cukup aktif, 6 orang siswa tidak aktif, dan 3 orang siswa sangat tidak aktif.

Hal ini didapatkan dari skor yang diperoleh masing-masing siswa pada 5 kategori pernyataan atau indikator keaktifan siswa, yaitu :

1. kesiapan mengikuti pelajaran,

2. kerjasama kelompok,

3. mengemukakan pendapat/ide,

4. bertanya jika menemukan kesulitan, dan

5. kedisiplinan mengumpulkan tugas, di mana setiap pernyataan bernilai positif diberi skor 1 .

Hasil observasi juga menunjukkan persentase jumlah siswa pada masing-masing indikator yaitu :

1. kesiapan mengikuti pelajaran (73\%),

2. kerjasama kelompok (79\%),

3. mengemukakan penda-pat/ide (26\%),

4. bertanya jika menemukan kesulitan (59\%), dan

5. kedisiplinan mengumpulkan tugas $(55 \%)$

Adapun keterangan jumlah skor yang diperoleh siswa adalah :

Skor 1 = Sangat Tidak Aktif

Skor 2 = Tidak Aktif

Skor 3 = Cukup Aktif

Skor 4 = Aktif

Skor 5 = Sangat Aktif

Selain data tersebut di atas, terjadi peningkatan keaktifan siswa 
setelah dilakukannya tindakan pada Siklus I, hal ini terlihat dari meningkatnya jumlah siswa yang mengumpulkan tugas, yaitu dari $65 \%$ pada prasiklus menjadi $86 \%$ pada siklus I. Begitu juga dengan persentase ketuntasan siswa dari $55 \%$ pada prasiklus menjadi $79 \%$ pada siklus I. Sebagaimana dalam table berikut ini :

Tabel Hasil Penugasan Siklus I

\begin{tabular}{|l|c|}
\hline Nilai Tertinggi & $\mathbf{9 5}$ \\
\hline Nilai Terendah & $\mathbf{0}$ \\
\hline Rata-rata & $\mathbf{7 0 , 2}$ \\
\hline Prosentase Ketuntasan & $\mathbf{7 9 \%}$ \\
\hline
\end{tabular}

Persentase ketuntasan di atas diperoleh berdsarkan data bahwa dari 29 orang siswa kelas VII D, 25 orang siswa (86\%) mengumpulkan tugas dan 4 siswa (14\%) tidak mengumpulkan tugas. Namun dari 25 orang siswa yang mengumpul-kan tugas, 23 orang siswa (79\%) mendapat nilai tuntas dan 2 orang siswa $(7 \%)$ mendapat nilai belum tuntas

Adapun interval nilai penugasan PraSiklus sebagaimana dalam table berikut ini:

Tabel Interval nilai penugasan Siklus I

\begin{tabular}{|c|c|c|}
\hline No & $\begin{array}{c}\text { Interval } \\
\text { Nilai }\end{array}$ & $\begin{array}{c}\text { Banyak } \\
\text { Siswa }\end{array}$ \\
\hline 1 & $0-50$ & 6 \\
\hline 2 & $51-60$ & 0 \\
\hline 3 & $61-70$ & 1 \\
\hline 4 & $71-80$ & 4 \\
\hline 5 & $81-90$ & 15 \\
\hline 6 & $91-100$ & 3 \\
\hline \multicolumn{2}{|c|}{ Jumlah } & 29 \\
\hline
\end{tabular}

\section{d. Refleksi}

Pada akhir pembelajaran observer melaporkan kepada guru berupa masukan secara lisan dan tulisan. Hasil refleksi pada siklus I menunjukkan bahwa aktivitas guru peneliti dengan menerapkan strategi
Moda Kombinasi dalam proses pembelajaran jarak jauh pada siswa kelas VII D SMPN 1 Labuhan Haji, sudah sesuai dengan rencana yang telah disusun sebelumnya, selain itu, hasil refleksi juga menunjukkan keberhasilan guru dalam menerap-kan strategi Moda Kombinasi, yaitu meningkatnya keaktifan siswa dalam pembelajaran IPS pada materi Interaksi Sosial walaupun belum sepenuhnya berhasil mencapai seluruh indikator keaktifan siswa

Hal yang perlu menjadi perhatian peneliti untuk ditingkatkan pada kegiatan siklus berikutnya adalah masih belum maksimalnya keaktifan siswa dalam hal mengemukakan pendapat/ide yang hanya mencapai $26 \%$, bertanya jika menemukan kesulitan 59\%, dan kedisiplinan mengumpulkan tugas $55 \%$.

Hal lain yang perlu dipertimbangkan dan dijadikan acuan pada rencana tindakan berikutnya adalah hambatan-hambatan yang menyebabkan belum optimalnya keaktifan siswa, yaitu : 1) peserta didik belum terbiasa belajar secara daring sehingga beberapa peserta didik masih terlihat kaku bahkan kurang mengerti materi yang dijelaskan guru. Keadaan ini dapat diantisipasi dengan meningkatkan frekwensi pendekatan secara luring dan membentuk kelompok belajar yang secara bergiliran dikunjungi oleh guru, 2) Ada sebanyak 3 orang diantara siswa yang tidak mengumpulkan tugas, tidak memiliki handphone sehingga siswa tersebut tidak dapat mengikuti pembelajaran secara daring dengan optimal. Keadaan ini dapat diantisipasi dengan usaha guru mendatangi siswa tersebut dan menjelaskan materi pelajaran secara luring, 3) peserta didik masih merasa malu dan ragu untuk 
bertanya, menjawab maupun berpendapat baik ditujukan pada teman kelompok ataupun gurunya. Keadaan ini membutuhkan motivasi dan kiat dari guru untuk memunculkan keberanian pada siswa.

\section{Deskripsi Siklus II}

Setelah rencana pembelajaran yang mengacu pada hasil refleksi pada siklus I dilaksanakan, antara lain dengan memantapkan penerapan Moda Kombinasi, dan lebih banyak memberikan motivasi pada pembelajaran siklus II. Dalam hal ini guru/peneliti lebih intens melakukan pembelajaran secara luring dengan mengunjungi kelompok-kelompok belajar pesertadidik yang sudah terbentuk.

Sebagaimana pada siklus I, dilakukan langkah-langkah pembela-jaran pada siklus II ini sebagai berikut:

a. Perencanaan

Pada perencanaan siklus II, guru /peneliti menyusun perangkat pembelajaran berupa RPP dengan materi "Bentuk-bentuk Interaksi Sosial", serta menyiapkan lembar observasi.

b. Pelaksanaan

Pada tahap pelaksanaan, berdasarkan hasil refleksi pada siklus I di atas maka dilakukan perbaikan pada siklus II.

Langkah-langkah pelaksana-an, sebagai berikut:

- Kegiatan Pendahuluan :

1) Menginformasika nmelalui WAG dan Microsoft Team.

2) Mengucap salam dan berdo'a, dilanjutkan dengan mengabsen siswa lewat WAG / Microsoft Team.

3) Apersepsi dan motivasi dengan menanyakan tentang materi tentang bentuk-bentuk interaksi sosial yang telah dikirim oleh guru/peneliti sehari sebelum pembelajaran pada siklus II.
- Kegiatan Inti :

Dilaksanakan secara Daring

Pertemuan I :

1) Membuka pembelajaran dengan voice call melalui WhatsApp.

2) Guru/peneliti menjelaskan materi pelajaran sesuai KD dalam RPP yang disiapkan yaitu tentang Bentuk-Bentuk Interaksi Sosial.

3) Memberikan kesempatan kepada siswa untuk bertanya jika ada yang belum dipahami ataupun mengungkapkan permasalahan yang ditemukan dari bahan bacaan yang telah dikirim oleh guru sebelumnya.

4) Membuka forum diskusi untuk memberikan kesempatan kepada kelompok lain menanggapi permasalahan yang ada.

5) Menyimpulkan dengan cara membuat rangkuman hasil pembelajaran dan menyelesaikan tugas yang diberikan guru secara tertulis.

6) Guru memberikan kesempatan kepada siswa untuk berdiskusi melalui WAG.

Dilaksanakan secara luring :

1) Siswa menyelesaikan tugas yang diberikan guru yaitu meminta siswa untuk membuat foto atau kegiatan yang berkaitan dengan contoh proses sosial asosiatif dan disosiatif.

2) Siswa mengirimkan tugasnya lewat WhatsApp / Microsoft Team.

Dilaksanakansecara Daring

Pertemuan II :

1) Membuka pembelajaran dengan voice call melalui WhatsApp.

2) Menjelaskan secara singkat materi pelajaran tentang Faktor-faktor penyebab terjadinya Interaksi Sosial.

3) Mempersilahkan siswa untuk bertanya jika ada yang belum 
dipahami dari penjelasan guru melalui voice call atau komen lewat WAG.

DilaksanakansecaraLuring :

1) Siswa menyelesaikan tugas yang diberikan guru berupa kuis.

2) Siswa mengirimkan tugasnya lewat WhatsApp / Microsoft Team.

c. Pengamatan

Pengamatan yang dilakukan peneliti bersama observer dengan mengisi lembar obsevasi menitik beratkan pada proses pembelajaran baik secara daring maupun luring.

Hasil pengamatan pada siklus II menunjukkan adanya peningka-tan di mana pada siklus I tidak ada siswa yang mendapat kategori sangat aktif namun pada siklus II terdapat 4 orang siswa sangat aktif, begitu juga siswa yang aktif pada siklus I hanya 10 orang, namun pada siklus II menjadi 21 orang, sedangkan untuk kategori siswa cukup aktif dan tidak aktif terjadi penurunan jumlah dari 10 orang siswa cukup aktif menjadi 1 orang siswa cukup aktif, dan 6 orang siswa tidak aktif menjadi 3 orang siswa tidak aktif serta tidak ada siswa dengan kategori sangat tidak aktif

Hasil observasi juga menunjukkan adanya peningkatan persentase jumlah siswa pada masingmasing indikator dari siklus I dan siklus II yaitu : 1. kesiapan mengikuti pelajaran dari $73 \%$ menjadi 86\%, 2. kerjasama kelompok dari $79 \%$ menjadi $86 \%, 3$. mengemukakan pendapat/ide dari $26 \%$ menjadi $66 \%$, 4. bertanya jika menemukan kesulitan dari $59 \%$ menjadi $73 \%$, dan 5 . kedisiplinan mengumpulkan tugas dari $55 \%$ menjadi $83 \%$.

Selain data tersebut di atas, terjadi peningkatan keaktifan siswa setelah dilakukannya tindakan pada Siklus II, hal ini terlihat dari meningkatnya jumlah siswa yang mengumpulkan tugas, yaitu dari $86 \%$ pada siklus I menjadi $97 \%$ pada siklus II. Begitu juga dengan persentase ketuntasan siswa dari $79 \%$ pada siklus I menjadi $93 \%$ pada siklus II. Sebagaimana dalam table berikut ini :

Tabel Hasil Penugasan Siklus I

\begin{tabular}{|l|c|}
\hline Nilai Tertinggi & $\mathbf{9 5}$ \\
\hline Nilai Terendah & $\mathbf{0}$ \\
\hline Rata-rata & $\mathbf{8 0}$ \\
\hline Prosentase Ketuntasan & $\mathbf{9 3 \%}$ \\
\hline
\end{tabular}

Persentase ketuntasan di atas diperoleh berdsarkan data bahwa dari 29 orang siswa kelas VII D, 28 orang siswa (97\%) mengumpulkan tugas dan 1 orang siswa (3\%) tidak mengumpulkan tugas. Namun dari 28 orang siswa yang mengumpul-kan tugas, 27 orang siswa (93\%) mendapat nilai tuntas dan 1 orang siswa (3\%) mendapat nilai belum tuntas

Adapun interval nilai penugasan PraSiklus sebagaimana dalam table berikut ini:

Tabel Interval nilai penugasan Siklus II

\begin{tabular}{|c|c|c|}
\hline No & $\begin{array}{c}\text { Interval } \\
\text { Nilai }\end{array}$ & $\begin{array}{c}\text { Banyak } \\
\text { Siswa }\end{array}$ \\
\hline 1 & $0-50$ & 1 \\
\hline 2 & $51-60$ & 1 \\
\hline 3 & $61-70$ & 3 \\
\hline 4 & $71-80$ & 5 \\
\hline 5 & $81-90$ & 16 \\
\hline 6 & $91-100$ & 3 \\
\hline \multicolumn{2}{|c|}{ Jumlah } & 29 \\
\hline
\end{tabular}

d. Refleksi

Pada akhir pembelajaran siklus II, observer kembali mela-porkan kepada guru mengenai hasil pengamatannya baik secara lisan maupun tulisan. Hasil refleksi pada siklus II menunjukkan bahwa penerapan Moda Kombinasi dalam 
proses pembelajaran jarak jauh yang dilakukan peneliti sudah berhasil meningkatkan keaktifan siswa dalam mengikuti proses pembelajaran jarak jauh pada kelas VII D SMPN 1 Labuhan Haji sehingga penelitian dicukupkan pada siklus II ini.

\section{PENUTUP}

\section{Simpulan}

Berdasarkan uraian hasil pene-litian dan pembahasan di atas, maka diperoleh kesimpulan bahwa penerapan moda kombinasi dapat meningkatkan keaktifan siswa dalam pembelajaran jarak jauh (Distance Learning) pada materi Interaksi Sosial di kelas VII D SMPN 1 Labuhan Haji Semester Ganjil Tahun Pelajaran 2020/2021. Hal ini dapat dilihat dari :

a. Terjadi peningkatan jumlah siswa yang memperoleh skor keaktifan 5 (sangat aktif) setelah dilakukannya tindakan pada siklus II, yaitu sebanyak 4 orang siswa dari yang sebelumnya tidak ada, begitu juga dengan siswa yang memperoleh skor 4 (aktif) dari 10 orang siswa pada siklus I menjadi 21 orang pada siklus II, sedangkan jumlah siswa dengan skor 3 (cukup aktif) mengalami penurunan dari 10 orang pada siklus I menjadi 1 orang pada siklus II, hal yang sama juga terjadi pada jumlah siswa dengan skor 2 (tidak aktif) maupun dengan skor 1 (sangat tidak aktif) dengan perbandingan masing-masing dari 6 orang siswa pada siklus I menjadi 3 orang siswa pada siklus II dan dari 3 orang siswa menjadi tidak ada atau 0 .

b. Terjadi peningkatan persentase jumlah siswa pada masing-masing indikator dari siklus I dan siklus II yaitu : 1 . kesiapan mengikuti pelajaran dari 73 $\%$ pada siklus I menjadi $86 \%$ pada siklus II, 2. kerjasama kelompok dari $79 \%$ menjadi $86 \%$, 3. mengemukakan pendapat/ide dari $26 \%$ menjadi $66 \%$,
4. bertanya jika menemukan kesulitan dari $59 \%$ menjadi $73 \%$, dan 5 . kedisiplinan mengumpulkan tugas dari $55 \%$ menjadi $83 \%$.

c. Terjadi peningkatan persentase ketuntasan siswa dari $79 \%$ pada siklus I menjadi 93\% pada siklus II.

2. Saran

Berdasarkan hasil pembahasan dan kesimpulan penelitian yang dikemukakan di atas, saran yang dapat dikemukakan bagi pihak-pihak yang terkait antara lain :

a. Bagi Sekolah

1) Agar menyiapkan fasilitas pembelajaran daring maupum luring, seperti ketersediaan jaringan internet dan modul pembelajaran.

2) Menjalin kerjasama dengan wali siswa agar memberikan izin kepada guru untuk melaksanakan pembelajaran luring dan bersamasama mengawasi kegiatan belajar siswa di rumah.

3) Menjalin Kerjasama dengan operator seluler untuk pengadaan kuota gratis bagi guru dan siswa.

b. Bagi Guru

1) Guru meluangkan waktu untuk mengunjungi / mengontrol kegiatan belajar siswa di rumah.

2) Berusaha membantu mencari solusi terhadap kendala yang dihadapi siswa dalam pembelajaran daring maupun luring.

3) Sebisa mungkin guru menguasai IT.

c. Bagi Peneliti

Para peneliti lain diharapkan
terus mengembangkan penelitian
tindakan kelas ini karena penelitian
tindakan kelas bertujuan untuk
menemukan pola tindakan yang tepat
untuk meningkatkan kualitas
pembelajaran.




\section{DAFTAR PUSTAKA}

Dimiyati dan Mudjiono, 2009. Belajar Dan Pembelajaran. Jakarta : PT. Rineka Cipta.

Ditjen Guru dan Tenaga Kependidikan, Menteri Pendidikan Dan Kebudayaan, Guru Pembelajar : Pedoman Program Peningkatan Kompetensi Moda Tatap Muka Dalam Jaringan (Daring) dan Daring Kombinasi.

Erlis Nurhayati, 2020. Jurnal Penelitian Dan Pengembangan Pendidikan. Jurnal Pedagogy Vol.7. No.3. Juli 2020.

Istarani, 2012. 58. Model Pembelajaran Inovatif, Medan Media Persada.

Kozma, 2007. Strategi Pembelajaran. Jakarta : PT. Rineka Jaya.

Mustakim, 2020. Journal Of Islamic Education Vol.2, No.1, May 2020. Al Asma.

Nana Sudjana, 2005. Hasil Dan Proses Belajar Mengajar, Bandung : Remaja Rosdakarya

Nana Sudjana, 2010. Belajar Siswa Aktif Dalam Proses Belajar Mengajar. Bandung : Sinar Baru Algensindo.

Pusat Pembinaan Dan Pengembangan Bahasa, 1998. Kamus Besar Bahasa Indonesia, Jakarta : Perum Balai Pustaka.

Sardiman, 2001. Interaksi Dan Motivasi Belajar Mengajar. Jakarta : Raja Grafindo Persada.

Shoimin, 2014. 68. Model Pembelajaran Inovatif Dalam Kurikulum 2013, Yogyakarta. Ar-Ruzz Media.

Soekartawi, 2003. E-Learning Di Indonesia Dan Prospeknya Di Masa Mendatang. Makalah Seminar Nasional "ELearning Perlu E-Library" Di Universitas Kristen Petra, Surabaya.

Stewart, Keagen, B.Holmberg dalam Aristo Rahadi (2008), Media Pembelajaran Dalam Pendidikan Jarak Jauh, Artikel.

Sukartawi, 2003, Blended E-Learning: Alternatif Model Pembelajaran Jarak
Jauh di Indonesia, Jurnal Seminar Nasional.

Sutanto Edhy, Konsep Dan Implementasi ELearning, Studi Kasus Pengem-bangan E-Learning di SMAN 1 Sentolo Yogyakarta. Jurnal (2009). 